Model Program

\title{
Development and Evaluation of an Inquiry-Based Elementary Science Teacher Education Program Reflecting Current Reform Movements
}

\author{
Gail R. Luera
}

School of Education, University of Michigan-Dearborn, Dearborn, MI 48128, U.S.A.

\section{Charlotte A. Otto}

College of Arts, Sciences, and Letters, University of Michigan-Dearborn, Dearborn, MI 48128, U.S.A.

\begin{abstract}
The National Science Education Standards (National Research Council 1996, National science education standards. Washington, DC: National Academy Press) and various other national and state documents call for teachers who possess science content knowledge, employ an inquiry approach in teaching, and engage in reflective practices. This paper describes a rationale for choosing particular recommendations to implement and how we incorporated those as we revised our elementary science education program. An analysis of the impact of the reformed inquiry-based content courses revealed that students who take more than one reformed content course improve their science content knowledge and efficacy towards teaching science significantly more than students who take fewer courses.
\end{abstract}

\section{Introduction}

Many states, including the state of Michigan, face similar problems in attracting well-qualified teachers to public K-12 schools. In particular, teacher attrition and retirement affect the quantity and quality of teachers in the classroom. Nationally, 30\% of certified teachers leave the profession within the first 5 years (Jehlen, 2001). Teacher retirement is particularly affecting Michigan, as it is projected that two thirds of Michigan's educators will be eligible to retire by 2010 (Michigan Federation of Teachers \& School Related Personnel, 2003). These difficulties provide teacher educators with a window of opportunity to impact significantly the quality of science teaching in $\mathrm{K}-12$ schools. Although better educated and trained teachers are needed in all subjects, science education is an area of particular concern: Research shows that elementary teachers are not comfortable teaching science, and, as a result, do not spend much time teaching it (McDevitt, Heikkinen, Alcorn, Ambrosio, \& Gardner 1993; Tobin, Briscoe, \& Holman, 1990; Young \& Kellogg, 1993). This paper describes and provides preliminary data for one solution to improve preservice elementary science teacher education by implementing an innovative science 
curriculum that is broadly relevant to issues faced by teacher educators across the United States.

\section{History of Reform}

Before describing the specifics of the curriculum renovation, it is important to consider what led to the development of our revised program. The process of reform at our university, the University of Michigan-Dearborn (UM-D), began nearly 10 years ago. At that time, elementary education students were required to take a course focusing on science process skills, the nature of science, and the experimental method (EXPS 220); two 4-credit science courses, each a lecture with an accompanying laboratory; an elective course in any science; and a science methods course for elementary teachers (EDD 485).

Both required science courses were survey courses taught to a wide variety of academic majors. The courses had been initially developed to address campuswide graduation requirements for science, not to provide science content for education majors alone. One course emphasized basic life processes, the fundamentals of chemistry and physics, and human systems and genetics. The other course focused on ecology, evolution, energy, energy technology, geology, and astronomy. The instructor, a science faculty member, determined course content. The course material was presented to more than $100 \mathrm{stu}-$ dents per section in a traditional manner of 3 hour lecture and 3 hour laboratory per week. The laboratory experience generally followed the lecture and confirmed the concepts presented in the lecture. Neither the required science courses nor the science elective had any explicit connection to state or national science standards.

Three factors led to the initiation of reform at UM-D. First, science education faculty in the School of Education (SOE) recognized that traditional lecturelaboratory pedagogy was the pedagogical method employed in the science content classes, but an inquiry approach was advocated and modeled in the two required science education courses. At the same time, a science education faculty member and a physicist were involved with the Michigan State Systemic Initiative (MSSI), a grant supported by the National Science Foundation. Two of the MSSI goals were to strengthen teacher preparation development and to develop detailed curricula based upon national science standards. Examination of our required content courses (the survey courses described above) revealed that the content reflected faculty preferences and interests rather than state or national science benchmarks.

The third factor was the informal development of a team of science educators from the School of Education and scientists from the College of Arts, Sciences, and Letters who understood and supported the need for changes in the science education curriculum. Involvement with the MSSI project and a National Science Foundation grant supporting science and mathematics reform provided the impetus to formalize the team and the resources to begin the reform. 


\section{Reformed Program Philosophy and Goals}

There were four crucial considerations guiding our program revision. These were (a) incorporating a social constructivist theory of learning; (b) basing instruction on the state and national content standards; (c) including instruction about big ideas, which are cross-disciplinary unifying themes in science; and (d) focusing on the development of reflective practice.

\section{Constructivist Learning Theory}

As UM-D's commitment to reform the elementary science education program solidified, team members examined the recommendations from the National Science Education Standards (NSES; National Research Council, 1996), the Michigan Curriculum Framework for Science (MCF-S; Michigan Department of Education, 2000a) and other reform documents, such as How People Learn (Bransford, Brown, \& Cocking, 2000) and Science for All Americans (American Association for the Advancement of Science, 1989). During this time, UM-D's School of Education adopted the Teaching for Understanding model as its framework for educating preservice teachers (University of Michigan-Dearborn, n.d.). Each of these documents endorses a constructivist learning theory. According to constructivism, humans actively and socially construct meaning (learn) and integrate new knowledge into their preexisting mental models of the world (Abdal-Haqq, 1998; Richardson, 1997). We concluded that the theoretical basis of any science curricular reform at UM-D would best be rooted in the epistemology of social constructivism. Our revised program needed to assist preservice teachers in developing practices that reflected on their prior knowledge and attitudes, while allowing them to consider alternative conceptions.

With its focus on the learner constructing knowledge within a group, inquirybased teaching represents a range of instructional approaches compatible with a social constructivist theory of learning. Within this context, the reformed program incorporated the NSES three-pronged definition of inquiry. Scientific inquiry "refers to the diverse ways in which scientists study the natural world and propose explanations based on the evidence derived from their work" (National Research Council, 1996, p. 23). Inquiry learning "refers to the activities of students in which they develop knowledge and understanding of scientific ideas, as well as an understanding of how scientists study the natural world" (p. 23). Inquiry teaching is defined as "providing a classroom where learners can engage in scientific oriented questions to formulate explanations based on evidence" (p. 29).

Because teachers teach as they were taught (Borko \& Putnam, 1996; Bryan \& Abell, 1999; Loucks-Horsley, Hewson, Love, \& Stiles, 1998; Zeichner \& Tabachnick, 1981), we recognized that we needed to infuse the inquiry-based pedagogy throughout our science education curriculum if we wanted our graduates to implement inquiry pedagogy in their own classrooms. Teachers, especially beginning teachers, often implement practices they have experienced as students, regardless of the effectiveness of the method, simply because the method is familiar. Given the 
isolation, lack of comfort, or both with inquiry-based pedagogy, many beginning teachers often adopt the traditional teaching methods of their colleagues. These are also the methods modeled by discipline-based faculty at colleges and universities in traditional science classes (Wyckoff, 2001).

\section{Content Standards}

In revising our program, it was important to recognize the demands for accountability placed on $\mathrm{K}-8$ teachers. Teachers in the United States are expected to follow the science benchmarks articulated in their state frameworks. In Michigan, this is the MCF-S (Michigan Department of Education, 2000a). The design for the science benchmarks in MCF-S was based on the NSES (National Research Council, 1996). These documents are remarkably similar in identifying content appropriate material by grade range and in specifying inquiry instruction as the preferred pedagogy in the classroom. In short, both MCF-S and NSES prescribe not only what should be taught, but also how it should be taught.

\section{Unifying Themes in Science}

An expert's knowledge is "connected and organized around important concepts" [emphasis added] (Bransford et al., 2000, p. 9), while a novice's knowledge is often fragmented (diSessa, 1993). Disconnected knowledge makes retrieval of relevant information and transferability to appropriate situations difficult (Van Heuvelen, 1991). Like other preservice teachers, our students generally possessed subject matter knowledge that was disjointed, compartmentalized, and not organized (Gess-Newsome, 1999). We reasoned that, if we wanted them to have a cognitive structure similar to that of experts, we needed to expose them to key scientific concepts. The NSES recommends that students understand and know about unifying themes or big ideas in science. Science for All Americans (American Association for the Advancement of Science, 1989) identifies several concepts or unifying themes in science, including scale, models, constancy and change, and systems.

UM-D's previous program did not explore any of the big ideas that unify science in a way that would help preservice teachers understand how different science disciplines think of, or use, these ideas. Our traditional science courses introduced these large, underlying concepts, but did not link them to other disciplines. It cannot be assumed that students will be able to integrate their knowledge simply because they have been introduced to such concepts. True integration of big ideas comes from developing a deeper understanding of the concept by additional exploration focused on how the concept is used and presented in different scientific disciplines.

\section{Reflective Practice}

Another goal of the reformed program was that the students develop two types of reflective practices. One term for reflection on what one knows and does not know is metacognition. The ability to reflect on one's performance and monitor one's 
knowledge is important because it increases transferability of knowledge (Bransford et al., 2000, p. 12) and allows the learner to know when they do not know something (p. 47). Self-reflective skills may also lead to greater conceptual understanding of science concepts (May \& Etkina, 2002). This type of reflection also promotes independent learning, a necessary skill for effective teachers (Bransford et al., 2000, p. 50).

The second type of reflective practice focuses on reflection-in-action, also called action research or, in this setting, teacher research. Engaging all teachers in research is emphasized by the NSES (National Research Council, 1996). Professional development standards recommend that the emphasis should be changed from teacher as consumer of knowledge about teaching to teacher as producer of knowledge about teaching. For teachers, action research, conducted in a classroom setting, is a more appropriate methodology than classical research. It is practical: It focuses on everyday problems and realistic solutions, while empowering teachers to become change agents in their classrooms and schools (Carr \& Kemmis, 1988). Action research has been mentioned as a key technique in supporting continuous improvement in teaching and learning (Hart \& Robottom, 1990; Tabachnick \& Zeichner, 1999; van Zee, 1998). Some believe it is especially important to offer reflective experiences, such as action research, early in a teaching career so new teachers can establish the habit of reflection (Abell \& Bryan, 1997; Collier, 1999; Goodnough, 2001; Ross, Rolheiser, \& Hogaboam-Gray, 1998; Yerrick \& Hoving, 2003).

In the previous science education program, there were limited opportunities for students to reflect on their science knowledge or on how they came to possess that knowledge. The extent to which reflective practice was overtly covered in each course was dependent upon the instructor. The scientists who taught content courses had little time or inclination to ask students to consider how they came to know science content and how that might affect their teaching. In the courses taught by the science educators (EXPS 220 and EDD 485), there was emphasis on thinking as a learner and as a teacher and on reflecting on the process of learning new concepts. However, none of the courses included a formal introduction to the field of reflective practice or action research.

\section{Revised Program}

The science education reform team at UM-D based all of the programmatic changes on the belief that integration of the entire learning experience for elementary preservice teachers is essential for supporting long-term adoption of inquiry teaching. Therefore we

- created three required content courses (one each in physical, life, and earthplanetary sciences);

- implemented a uniform inquiry-based pedagogy throughout the entire science curriculum, especially in the three newly created science content courses;

- required content to be tied to the MCF-S and NSES; 
Table 1

Comparison of Previous and Revised Elementary Science Education Programs

\begin{tabular}{|c|c|c|c|}
\hline \multicolumn{2}{|c|}{ Required courses in old program } & \multicolumn{2}{|c|}{ Required courses in revised program } \\
\hline $\begin{array}{l}\text { Science process skills (EXPS } \\
222)^{\mathrm{a}}\end{array}$ & 3 credits & $\begin{array}{l}\text { Science process skills (EXPS } \\
\text { 220) }\end{array}$ & 3 credits \\
\hline $\begin{array}{l}\text { Integrated science course } \\
\quad(\text { NSCI 120) }\end{array}$ & 4 credits & $\begin{array}{l}\text { Learning by inquiry: Physical } \\
\text { science (NSCI 231) }\end{array}$ & 3 credits \\
\hline $\begin{array}{l}\text { Integrated science course } \\
\quad(\mathrm{NSCI} 121)^{\mathrm{a}}\end{array}$ & 4 credits & $\begin{array}{l}\text { Learning by inquiry: } \\
\text { Earth-space science } \\
(\text { NSCI 232) }\end{array}$ & 3 credits \\
\hline $\begin{array}{l}\text { Science content course } \\
\quad(\text { elective })^{\mathrm{a}}\end{array}$ & 3 credits & $\begin{array}{l}\text { Learning by inquiry: Life } \\
\text { science (NSCI 233) }\end{array}$ & 3 credits \\
\hline \multirow[t]{2}{*}{$\begin{array}{l}\text { Science methods course } \\
\qquad(\text { EDD } 485)^{\mathrm{a}}\end{array}$} & 3 credits & $\begin{array}{l}\text { Science methods course } \\
\text { (EDD 485) }\end{array}$ & 3 credits \\
\hline & & $\begin{array}{l}\text { Science capstone course } \\
\quad(\text { EXPS 420) })^{\mathrm{b}}\end{array}$ & 2 credits \\
\hline Total credits & 17 credits & & 17 credits $^{b}$ \\
\hline
\end{tabular}

${ }^{\mathrm{a}}$ Courses can be taken in any sequence.

${ }^{\mathrm{b}}$ This will be a 3-credit course starting Fall 2004; the total credits will increase to 18.

- revised one existing course, Exploratory Studies (EXPS) 220: Science for Elementary Teachers, and made it the prerequisite for the new content courses;

- incorporated Education (EDD) 485: Methods of Teaching Science in Elementary and Middle School into the sequence to provide a theoretical perspective and field experience using the inquiry approach;

- developed a capstone course focusing on a scientific big idea (i.e., systems) and required students to conduct an action research project addressing student misconceptions about the course big idea; and

- created assignments throughout all the courses to foster development of reflective practice.

See Table 1 for a comparison of the old and revised programs. It is important to note that initially the total number of credits in the old and revised science education programs was unchanged. The total number of credits has now been increased by one to reflect the amount of work required in the capstone course.

\section{New Science Content Courses}

Inquiry pedagogy was incorporated throughout all science content courses by mandating the use of the learning cycle approach: engagement, exploration, explanation, and expansion. This form of guided inquiry is an effective way to learn science concepts (Guzzetti, Taylor, Glass, \& Gamas, 1993; Renner, Abraham, \& Birnie, 1988). The instructor begins each class session by setting the context (the 
engage). Next, teams of students work together to explore the science concept. Explanations are led by the course instructor and are based on results reported by student investigative groups. The class session concludes with students applying the concept to other contexts (the expansion). Each course consists of two 2-hour sessions per week; each is composed of three units or modules of varying length.

However, we knew it would be impossible, in the time available, to teach in an inquiry mode and to cover the entire content delineated by the state science standards. So we further focused the curriculum by examining the content of the fifth- and eighth-grade Michigan Education Assessment Program (MEAP; Michigan Department of Education, 2000b) tests. The concepts addressed on the MEAP tests were important to teach to our preservice students as these concepts reflect the content that our students will be accountable for teaching to their students. For example, in the life science course, a decision was made to focus on the hydrologic, carbon, and oxygen cycles, not phosphorus or sulfur cycles.

\section{Capstone Course}

One goal of our reformed program was to provide students with an experience that integrates the knowledge of science gained in several discrete disciplinary courses in terms of the unifying themes or big ideas of science. To achieve this goal, we created a unique capstone course that would focus on one of the unifying themes. Students would enroll in the capstone course after completing all three science content courses and the science methods course. The capstone course enables students to look anew at a big idea they encountered in science content courses.

The 3-credit capstone course consists of inquiry-based activities that are structured so teams of students engage in deep discovery explorations on one of the big ideas of science. In general, the capstone begins with an assessment of students' prior knowledge of that semester's big idea. As the semester progresses, students engage in specific exploration activities that confront the misconceptions or lack of knowledge identified in the initial assessment. We have found that the students are much more invested in learning once they realize they possess misconceptions or a lack of knowledge about the big idea. This approach to instruction has been used with the unifying themes of energy, systems and interactions, and scale and structure.

The second goal of the capstone class was to provide students with an opportunity to engage in action research, a type of reflective practice. In keeping with our philosophy of modeling appropriate pedagogy throughout the science curriculum, capstone faculty model the process of action research. Class discussion introduces students to the goals and processes of action research. During the term, teams of preservice teachers apply what they have learned about action research by probing $\mathrm{K}-8$ student misconceptions about the big idea they are simultaneously exploring in the capstone. The process of identifying $\mathrm{K}-8$ student misconceptions helps capstone students reflect on their own understanding of the big idea. 


\section{Integration of Reflective Practice}

One of the goals of the reformed program was to develop reflective practitioners, that is, possessing knowledge about their own learning styles and producing knowledge about teaching. It was apparent that a systematic commitment to this goal needed to be integrated into the reformed program. One kind of reflection, action research, became a focus of the capstone course (see above). A more personal, metacognitive form of reflection was still needed in the other courses if students were to develop skills that could lead to improvements in their conceptual understanding.

In the reformed program, students begin in the program's prerequisite introductory course (EXPS 220), not only to learn about what they know about science, but also to reflect upon how they came to their present understandings and beliefs. The students' reflective practices begin with a science autobiography. This report requires that students describe their previous experiences with science, read a biographical account of a scientist, and compare and contrast their experiences with science with that of the scientist.

Each of the content courses now has multiple reflective experiences. For example, one assignment requires that students write a paper in which they reflect about what they know and how they have developed and broadened their understanding of science content. For this assignment, students are asked to identify one or more concepts they did not understand at the beginning of the course and describe how they gained insight into that concept during class inquiry activities. Students are asked to demonstrate their understanding of the concept and an awareness of their learning process.

Another reflective activity is adapted from Etkina's weekly reports (Etkina, 2000; Etkina \& Harper, 2002; May \& Etkina, 2002). Students compose a written reflection that answers three questions:

1. What and how did you learn this week?

2. What questions remained unclear?

3. If you were the professor, what questions would you ask to find out whether or not the students understood the most important material of this week?

These weekly reports help students to reflect on their knowledge and to learn how to ask questions (Etkina, 2000). The content course instructors are discovering, as did Etkina \& Harper (2002), that students expect credit for their reflections, examples are needed to encourage deep student thinking, and that there is generally an initial resistance to the weekly assignments. Student negativity towards these assignments has decreased as the reflective assignments have been integrated into all of the science education courses.

A Web-based electronic portfolio was created to capture each reflective assignment. As each student progresses through the course sequence, papers and assignments are added to each student's portfolio as web pages. See http://www.umd.umich.edu/sep for an overview of the portfolio and http://www. umd.umich.edu/sep/example for selected student portfolios. 


\section{Program Evaluation}

The ultimate goal of the reformed elementary science program is to develop K-8 teachers who have sufficient science content knowledge and efficacy towards teaching science and who teach using an inquiry approach. Consequently, evaluation of the reformed elementary science education program focuses on three related constructs: our students' science content knowledge, our students' efficacy towards teaching science, and our students' teaching behavior.

The connections between content knowledge, efficacy, and teaching behavior is documented in the research literature. Differences in teacher efficacy can be observed in differences in teacher practices (Kronberg, 1999; Smylie, 1990). Education students' sense of efficacy about teaching science is linked to the way they are taught science and their understanding of science (Bell, 2001; Enochs \& Riggs, 1990). Teachers with a high sense of efficacy are more likely to utilize student focused or inquiry-based lessons (Sottile, Carter, \& Watson, 2001; Watters \& Ginns, 2000).

\section{Content Knowledge}

Measures of content knowledge are primarily assessed through the Michigan Educational Assessment Program 11th-grade Model Assessment (Michigan Department of Education, 2000b). This science test of released items contains 49 multiple choice and open-ended questions relating to life, physical, and earth-space science, as well as questions that determine students' abilities to construct and reflect upon their science knowledge and perform text analysis. All of the questions are correlated to the MCF-S. This alignment made this assessment tool particularly appropriate for use with our UM-D preservice teachers since our reformed content courses focus on the content addressed in the MCF-S. The maximum score for the overall MEAP is 63 .

\section{Students' Efficacy Towards Teaching Science}

We used the Science Teaching Efficacy Behavior Instrument Version B (for preservice teachers; Enochs \& Riggs, 1990) to evaluate our students' efficacy towards teaching science. The STEBI B includes 23 Likert-type scaled statements relating to personal beliefs about teaching science. It contains two subscales, personal science teaching efficacy beliefs and science teaching outcome expectancy, based upon Bandura's (1977) social cognitive theory, which states that self-efficacy beliefs motivate people towards specific actions and can be used to predict future behavior. The first subscale measures students' beliefs in their ability to teach science, while the outcome expectancy measures their beliefs that their teaching will make a difference in their students' understanding of science. Enochs and Riggs (1990) provided a complete description of the reliability and validity measures for STEBI B. The maximum score is 115 for the overall STEBI. 


\section{Data Collection and Findings}

This preliminary analysis focused on efficacy and content knowledge. Presently, we are not able to include behavior in our analysis due to a limited sample size. Issues related to collecting teaching behavior data will be discussed in a later section. Our initial evaluation sought to identify the impact of the reformed inquiry-based content courses on students' efficacy and content knowledge. The courses model inquiry-based teaching and constructivist acquisition of science knowledge. Because of the complex and dynamic nature of the courses, even if we clarified the relationship between content knowledge, efficacy, and the courses, it would be difficult to identify precisely which aspects of the inquiry course(s) affect efficacy and content knowledge uniquely.

The analysis sample consisted of students enrolled in the science methods course between Fall 2000 and Winter 2004. Generally students enroll in this course the semester before they student teach. The data reported here were collected in the first 3 years of the reform effort and represent preliminary findings as we have a limited number of students who have completed the reformed program. The data collected are from students who have completed the old program $(n=119)$ or the reformed program of all three inquiry-based content courses $(n=21)$ and from transfer students who completed a "semi-reformed" program $(n=145)$, including a mix of traditional courses and reformed courses.

To test the effect of the number of inquiry courses on science content knowledge, the overall MEAP score and subscores were analyzed with a one-way analysis of variance (ANOVA; see Table 2) The differences in means between the three groups were significant for the overall MEAP score, $F(3,265)=3.58, p<.05$, and the subfactors of the earth-space science knowledge, $F(3,261=2.97, p<.05$; constructing knowledge score, $F(3,265)=2.75, p<.05$, and text analysis score, $F(3,245)=3.00, p<.05$. A least squared difference $(L S D) t$ test with an alpha value of .05 showed that students who completed two inquiry content courses ( $M=43.67)$ scored significantly higher in overall content knowledge than students who completed zero $(M=40.34)$ or one inquiry course $(M=40.44)$. There was not a significant difference in overall MEAP scores between students who completed two or three content courses $(M=43.65)$. In terms of earth-space science knowledge, two inquiry courses again were the optimum number $(M=20.39)$, versus zero inquiry courses $(M=12.64)$, one inquiry course $(M=17.29)$ and three inquiry courses $(M=13.24)$. A final MEAP-related post hoc comparison revealed that students who completed two inquiry courses $(M=4.64)$, scored significantly better in the text analysis portion of the exam than students who completed one inquiry course $(M=3.88)$. There were no other significant differences between groups.

If the impact of the inquiry-based content courses is measured by science content knowledge (as measured by the MEAP), the data suggest that two inquiry courses are optimal. Why do students who completed all three courses not score the highest? One reason may be that the power to detect a significant difference is limited since the sample of students who have completed all three-inquiry courses is small. In the future, as more students finish the complete reformed program, our ability 


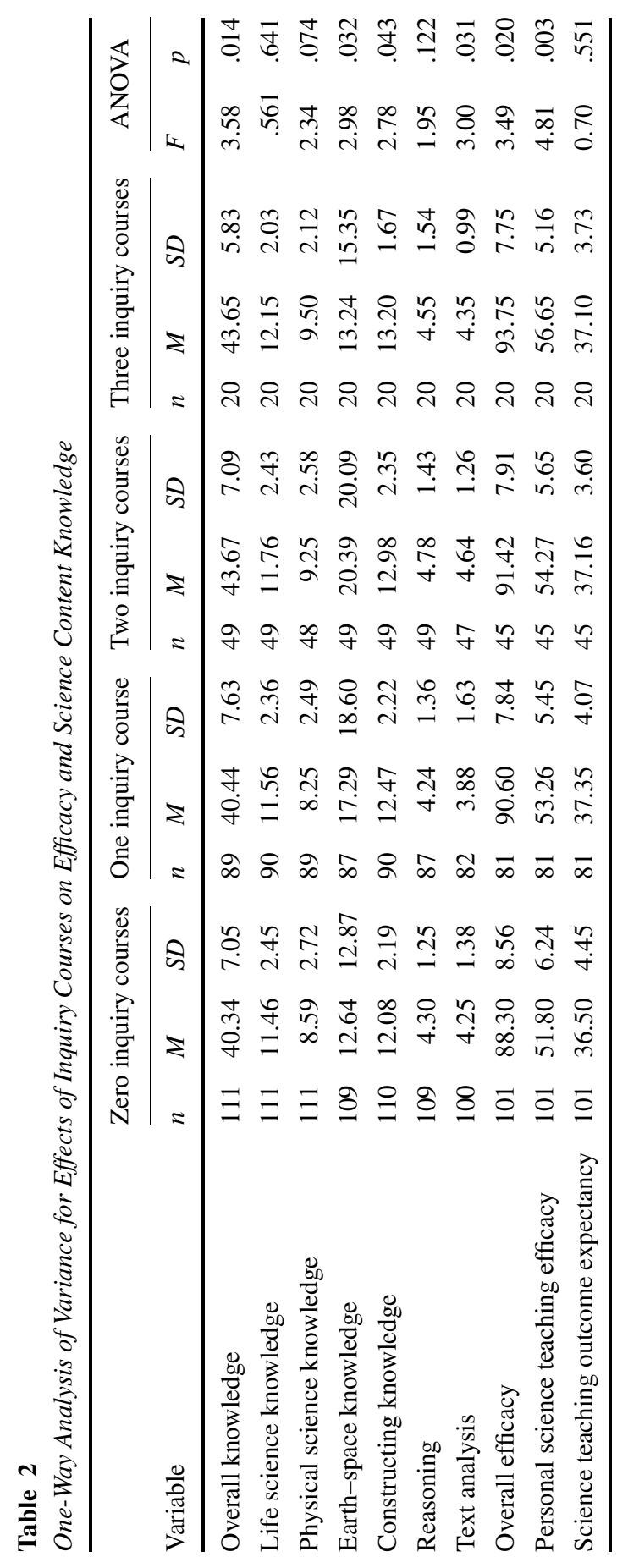


to detect the full effect of completing three inquiry content courses may become more evident. Regardless, it would be worth investigating why students who have completed two inquiry courses score so much higher in earth-space knowledge than students who completed all three.

A similar analysis (Table 2) was completed to test the effect of the number of inquiry courses on efficacy as measured with the STEBI-B. The results were significant for the overall STEBI score, $F(3,243)=3.49, p<.05$, and the preservice teacher efficacy beliefs subscore, $F(3,243)=4.81, p<.01$. The teacher outcome expectancy subscore did not differ based upon number of inquiry courses completed. Previous studies (Cantrell, Young, \& Moore, 2003; Traik, 2000) have indicated that this factor is resistant to change. Perhaps other factors in addition to content knowledge and experiencing inquiry learning as a student are responsible for preservice teachers' beliefs that their teaching will make a difference in their students' understanding of science.

Further LSD analysis identified that the difference in means occurred for students who completed two $(M=91.42)$ or three $(M=93.75)$ inquiry courses. These students possessed significantly higher overall efficacy towards teaching science when compared to students who took no inquiry content courses $(M=88.30)$. Completing one inquiry course $(M=90.60)$ versus zero was not significant $(p=.059)$. Apparently, more than one course is required to positively impact a student's efficacy towards teaching science.

Students completing three inquiry courses $(M=56.65)$ scored significantly higher in teacher efficacy beliefs than students who completed one $(M=53.26)$ or zero inquiry courses $(M=51.80)$. Students who completed two or three inquiry courses did not score significantly differently on this factor. In addition, students who completed two courses scored significantly higher $(M=54.27)$ on this subfactor than students who did not complete any inquiry courses. The results again demonstrate that more than one inquiry course is needed to increase a preservice teacher's belief in his or her ability to teach science.

\section{Future Research}

Areas of future research will be directed toward determining the long-term impact of the program on our alumni's science content knowledge and teaching practices. Investigating the durable effects of our program revisions could have significance for anyone seeking to make a lasting difference in how science is taught in elementary school.

To assess teaching practice, we intend to observe our alumni teach science and to evaluate their pedagogy utilizing the Reformed Teaching Observation Protocol (RTOP; Piburn \& Sawada, n.d.; Sawada et al., 2002). This instrument measures the extent to which a teacher uses reformed (constructivist or inquiry-based) pedagogy. It will take several years to obtain answers to these questions. To obtain a preliminary idea about our alumni's ability to use the inquiry approach, we have begun videotaping volunteers from our student teacher population. During the 2002-2003 school year, we asked more than 200 elementary education majors who were student 
teaching if we could videotape them teaching a science lesson. Only seven videotapes were ultimately made. There were numerous barriers prohibiting our taping of science lessons. These included scheduling conflicts with the videographer or the student teacher's fear of being videotaped. A significant number responded that their cooperating teacher "would not allow them to teach science the way we taught them" (using an inquiry approach), so they did not want us to see them teach. The necessity of getting parental permission for every child in the student teacher's classroom made some cooperating teachers or school principals limit participation. To reduce these barriers, we are recruiting our university supervisors and training them to evaluate student teachers with the RTOP. Observation and evaluation of teaching is already a part of the supervisors' duties; we are simply asking that everyone use a standard instrument. On-site evaluations that are required, rather than optional, will undoubtedly increase our sample size.

Alumni of this program will also be interviewed to determine their perceptions of, and reasons behind, their teaching behavior. Interview questions will help us learn why teachers use a specific pedagogy and also assist in the identification of any enduring effects of the content courses upon science content knowledge and how teachers view science (as discrete facts or composed of interdisciplinary big ideas). Other questions in the interview might focus on the alumni's current levels of reflective practice.

Another intriguing question we plan to investigate is why some science faculty are resistant to using inquiry pedagogy, while others make the transition willingly. Determining the answer becomes crucial as all reformed programs need to recruit additional faculty members to teach the inquiry-based courses. This issue has been explored within the context of particular professional development activities (Sunal et al., 2001) and a single course (Gess-Newsome, Southerland, Johnston, \& Woodbury, 2003). How reformed programs are maintained over time as members leave and new faculty need to be recruited is a larger issue to be investigated.

Once the reformed program evaluation has been completed, these larger issues and the long-term effects of program elements, such as specific content courses or the capstone course will be studied. The capstone course is a unique feature of the program that deserves, and will receive, the focus of another article.

\section{Conclusion}

Systemic change in education programs can be a slow and laborious process, necessitating the commitment and dedication of individuals at all levels. The challenges surrounding reform make it even more imperative that descriptions of program changes be shared so that both stories of success and struggle find a wider audience. Our goal was to provide a description of the development and initial evaluation of a reformed program, along with illustrative examples or findings (i.e., inquiry-based learning does increase science content knowledge) that will be useful to faculty seeking to reform their science education programs.

The initial program evaluation findings are similar to results demonstrating that social constructivist pedagogy led to greater gains in science content knowledge 
for university students compared to traditional teaching (i.e., lectures; Marshall \& Dorward, 2000; Tien, Roth, \& Kampmeier, 2002; Wyckoff, 2001). Our findings add to this body of research by providing a different context as we focused on a required program for elementary education students. The UM-D program illustrates the impact that multiple experiences with inquiry-based learning from both a student and a preservice teacher perspective can have on science content knowledge and efficacy towards science teaching.

UM-D's program, with its strong connections between inquiry pedagogy and science content in multiple required courses and with its culminating capstone course focusing on action research and big ideas in science, is unique. Despite its uniqueness, parts or the whole program may be adopted to a wide variety of settings. At present, a community college and a university are implementing different parts of the program.

In 2000-2001, SOE received an Eisenhower grant from the state of Michigan to provide training in inquiry pedagogy, a required component of the new science content courses, for community college science faculty. The grant also financially supported the community college faculty as they cotaught the course at UM-D. This provided long-term modeling of both teaching methods and content covered in each course. Two local community colleges are now offering the life science inquiry-based course to their preeducation students.

During the past 2 years, UM-D faculty have shared our reformed program's lesson plans and course goals with science and education faculty at the University of Illinois-Chicago (UIC). Beginning in Fall 2003, UIC implemented a set of four new science courses that will allow preservice teachers to experience and learn science in an integrated way that highlights unifying themes and helps students develop fundamental understandings, along with appreciation of the nature and history of scientific work. By sharing resources and building upon each other's work, universities and colleges can be substantive forces behind the creation of the next generation of high-quality teachers who implement reformed science curricula based on national science standards.

\section{Acknowledgments}

Federal support was critical for the development and implementation of science education reform at UM-D. Without federal funds from the Fund for the Improvement of Postsecondary Education (FIPSE; grant number P116B000759) and a National Science Foundation grant (DUE 9652117), we would have been extremely limited in the scope and rate at which we could improve our program.

\section{References}

Abdal-Haqq, I. (1998). Constructivism in teacher education: Considerations for those who would link practice to theory. (ERIC Digest No. ED 
426 986.) Retrieved on June 1, 2004, from http://www.ericfacility.net/ databases/ERIC_Digests/ed426986.html.

Abell, L., \& Bryan, S. (1997). Development of professional knowledge in learning to teach elementary science. Journal of Research in Science Teaching, 36, 121-139.

American Association for the Advancement of Science. (1989). Science for all Americans. New York: Oxford University Press. [Electronic version] http://www.project2061.org/tools/sfaaol/sfaatoc.htm.

Bandura, A. (1977). Self-efficacy: Toward a unifying theory of behavioral change. Psychological Review, 84, 191-215.

Bell, G. L. (2001, March). Reflective journal writing in an inquiry-based science course for elementary preservice teachers. Paper presented at the annual meeting of the National Association of Research on Science Teaching, St Louis, MO.

Borko, H., \& Putnam, R. T. (1996). Learning to teach. In R. C. Calfee \& D. Berliner (Eds.), Handbook on educational psychology (pp. 673-708). New York: Macmillan.

Bransford, J., Brown, A., \& Cocking, R. (Eds.). (2000). How people learn (expanded version). Washington, D.C.: National Academy Press.

Bryan, L. A., \& Abell, S. K. (1999). Development of professional knowledge in learning to teach elementary science. Journal of Research in Science Teaching, 36, 121-139.

Cantrell, P., Young, S., \& Moore, A. (2003). Factors affecting science-teaching efficacy of preservice elementary teachers. Journal of Science Teacher Education, 14, 177-192.

Carr, W., \& Kemmis, S. (1988). Becoming critical: Education, knowledge and action research. Philadelphia: Falmer Press.

Collier, S. T. (1999). Characteristics of reflective thought during the student teaching experience. Journal of Teacher Education, 50, 173-181.

diSessa, A. (1993). Toward an epistemology of physics. Cognition and Instruction, 10, 105-225.

Enochs, L. G., \& Riggs, I. M. (1990). Further development of an elementary science teaching efficacy belief instrument: A preservice elementary scale. School Science and Mathematics, 90, 694-706.

Etkina, E. (2000). Weekly reports: A two-way feedback tool. Science Education, 84, 594-605.

Etkina, E., \& Harper, K. A. (2002). Weekly reports: Student reflections on learning. Journal of College Science Teaching, 31, 476-480.

Gess-Newsome, J. (1999). Knowledge and beliefs about subject matter. In J. G. Gess-Newsome \& N. G. Lederman (Eds.), Examining pedagogical content knowledge: The construct and its implications for science education (pp. 5994). Boston: Kluwer Academic Publishers.

Gess-Newsome, J., Southerland, S. A., Johnston, A., \& Woodbury, S. (2003). Educational reform, personal practical theories, and dissatisfaction: The anatomy of 
change in college science teaching. American Educational Research Journal, $40,731-767$.

Goodnough, K. (2001). Teacher development through action research: A case study of an elementary teacher. Action in Teacher Education, 23(1), 37-46.

Guzzetti, B., Taylor, T. E., Glass, G. V., \& Gamas, W. S. (1993). Promoting conceptual change in science: A comparative meta-analysis of instructional interventions from reading education and science education. Reading Research Quarterly, 28, 117-159.

Hart, E., \& Robottom, I. (1990). The science technology-society movement in science education: A critique of the reform process. Journal of Research in Science Teaching, 27, 575-588.

Jehlen, A. (2001). An open secret [Electronic version]. NEAToday Online, 19(8). Retrieved February 2, 2004, from http://www.nea.org/neatoday/0105/cover.html

Kronberg, R. (1999). Teacher efficacy in heterogeneous fifth- and sixth-grade classrooms: Weaving teachers' practices and perspectives. University of Minnesota, Institute on Community Integration. (ERIC Document Reproduction Service No. ED 429 385).

Loucks-Horsley, S., Hewson, P. W., Love, N., \& Stiles, K. E. (1998). Designing professional development for teachers of science and mathematics. Thousand Oaks, CA: Corwin Press.

Marshall, J. A., \& Dorward, J. T. (2000). Inquiry experiences as a lecture supplement for preservice elementary teachers and general education students. Physics Education Research, American Journal of Physics Supplement, 68, S27-S36.

May, D. B., \& Etkina, E. (2002). College physics students' epistemological selfreflection and its relationship to conceptual learning. American Journal of Physics, 70, 1249-1258.

McDevitt, T. M., Heikkinen, H. W., Alcorn, J. K., Ambrosio, A. L., \& Gardner, A. P. (1993). Evaluation of the preparation of teachers in science and mathematics: Assessment of preservice teachers' attitudes and beliefs. Science Education, 77, 593-610.

Michigan Department of Education. (2000a). Michigan curriculum frameworkscience benchmarks. Retrieved June 8, 2004, from http://www.michigan.gov/ documents/Updated_Science_Benchmarks_27030_7.pdf.

Michigan Department of Education. (2000b). Michigan Educational Assessment Program, High School Test Science: Model of the assessment. Retrieved June 3, 2004, from http://www.meritaward.state.mi.us/mma/science/SC11s.pdf.

Michigan Federation of Teachers \& School Related Personnel. (January 13, 2003). Political action: It's about the issues! Retrieved May 18, 2004, from http:// www.mftsrp.org/political.html.

National Research Council. (1996). National science education standards. Washington, DC: National Academy Press.

Piburn, M., \& Sawada, D. (n.d.). Reformed teaching observation protocol (RTOP) reference manual (ACEPT Tech. Rep. IN00-3). Phoenix: Arizona State University, Arizona Collaborative for Excellence in the Preparation of Teachers. 
Renner, J. W., Abraham, M. R., \& Birnie, H. H. (1988). The necessity of each phase of the learning cycle in teaching high-school physics. Journal of Research in Science Teaching, 25, 39-58.

Richardson, V. (1997). Constructivist teaching and teacher education: Theory and practice. In V. Richardson (Ed.), Constructivist teacher education: Building new understandings (pp. 3-14). Washington, DC: Falmer Press.

Ross, J., Rolheiser, C., \& Hogaboam-Gray, A. (1998). Skills training versus action research in-service: Impact on student attitudes to self-evaluation. Teaching and Teacher Education, 14, 463-477.

Sawada, D., Piburn, M., Judson, E., Turley, J., Falconer, K., Benford, R., \& Bloom, I. (2002). Measuring reform practices in science and mathematics classrooms: The reformed teaching observation protocol. School Science and Mathematics, 102, 245-253.

Smylie, M. (1990). Teacher efficacy at work. In P. Reyes (Ed.), Teachers and their workplace (pp. 48-66). Newbury Park, CA: Sage.

Sottile, J., Carter, W., \& Watson, G. (2001, February). Increasing science achievement and student development as related to practicing teachers' self-efficacy. Paper presented at the annual meeting of the Eastern Educational Research Association, Hilton Head, SC.

Sunal, D., Sunal, C., Whitaker, K., Freeman, L., Odell, M., Hodges, J., et al. (2001). Faculty professional development and barriers to change. School Science and Mathematics, 101, 246-257.

Tabachnick, B., \& Zeichner, K. (1999). Idea and action: Action research and the development of conceptual change teaching of science. Science Education, 83, 309-322.

Tien, L.T., Roth, V., \& Kampmeier, J.A. (2002). Implementation of a peer-led learning instructional approach in an undergraduate organic chemistry course. Journal of Research in Science Teaching, 39, 606632.

Tobin, K., Briscoe, C., \& Holman, J. R. (1990). Overcoming constraints to effective elementary teaching. Science Education, 74, 409-420.

Traik, T. (2000). The impact of prior course experience and achievement on the science teaching self-efficacy of preservice elementary teachers. Journal of Elementary Science Education, 12(2), 21-31.

University of Michigan-Dearborn. (n.d.) Teaching for understanding. Retrieved June 1, 2004, from http://www.soe.umd.umich.edu/soeweb/soeinfo/tfu.htm

van Zee, E. (1998). Fostering elementary teachers research on their science practices. Journal of Teacher Education, 49, 245-254.

Van Heuvelen, A. (1991). Learning to think like a physicist: A review of research-based instructional strategies. American Journal of Physics, 59, 891897.

Watters, J., \& Ginns, I. (2000). Developing motivation to teach elementary science: Effect of collaborative and authentic learning practices in preservice education. Journal of Science Teacher Education, 11, 301-321. 
Wyckoff, S. (2001). Changing the culture of undergraduate science teaching. Journal of College Science Teaching, 30, 306-312.

Yerrick, R. K., \& Hoving, T. J. (2003). One foot on the dock and one foot on the boat: Differences among preservice science teachers' interpretations of fieldbased science methods in culturally diverse contexts. Science Education, 87, 390-418.

Young, B. J., \& Kellogg, T. (1993). Science attitudes and preparation of preservice elementary teachers. Science Education, 77, 279-291.

Zeichner, K., \& Tabachnick, R. (1981). Are the effects of university teacher education washed out by school experience? Journal of Teacher Education, 32, 7-11.

This manuscript was accepted under the editorship of Craig Berg and Larry Enochs. 